\title{
Dynamic Analysis of the Role of Thermal Inertia in the Heating System Control of Historical and Monumental Buildings
}

\author{
Vania Malaguti*, Chiara Lodi, Paolo Tartarini \\ Dept. of Engineering “Enzo Ferrari”, Via Vivarelli 10/1, 41125 Modena, Italy
}

Corresponding Author Email: vania.malaguti@unimore.it

https://doi.org/10.18280/ti-ijes.632-430

Received: 11 March 2019

Accepted: 5 May 2019

\section{Keywords:}

energy efficiency, heritage, thermal inertia, dynamic modelling

\begin{abstract}
Italy and Europe have a significant amount of historical heritage buildings that mark their cultural and social foundations and need to be protected. The majority of these buildings have poor energy performance and significant energy consumption.

The particularity of this type of buildings is the high thermal inertia given by the thickness of the massive walls, which should be taken into account when designing and controlling the thermal system.

The purpose of this study is therefore to present a methodology to evaluate the effect of thermal inertia and propose a solution of heating system control that takes into account this aspect.

The building chosen as case study is the Ducal Palace of Modena, one of the most emblematic and important historical buildings of Italy. The Palace is located in the city of Modena, in northern Italy and the building is currently home of the oldest military academy of Italy.

The results show that the use of a heating system control that takes into account the thermal inertia of the building improves comfort and allows reducing energy consumption.
\end{abstract}

\section{INTRODUCTION}

Nowadays buildings account for about $40 \%$ of the total energy consumption of the European Union (EU) and the share is continuously expanding [1]. Around a quarter of the existing buildings stock in Europe was built prior to the middle of the last century [2]. The problem is particularly relevant in countries like Italy, where about $20 \%$ of the existing buildings were built before 1919 [3] and about $40 \%$ of world artistic heritage can be found according to UNESCO estimates [4]. Over 4,000,000 of the 5,367,000 monuments worldwide are located in Italy $[5,6]$. These monuments often house public administrations, offices and dwellings, which have the common characteristics of poor energy performance and high energy demand.

A significant number of historical and monumental buildings are poorly insulated and use conventional inefficient fossil-fuel-based energy systems, typically associated with high energy costs and $\mathrm{CO}_{2}$ emissions. Despite of the relatively high energy need, indoor thermal comfort is often scarce. The most common reasons for discomfort are related with insufficient local thermal control, poor insulation, single glazed windows with air infiltration, large vertical temperature gradients and inadequate mean radiant and operative temperatures perceived by the occupants. Many energy retrofitting solutions are not compatible with historic buildings, especially for listed or protected ones. In such cases, "noninvasive" but often less performing solutions have to be chosen [7], sometimes associated with a higher investment cost than Best Available Technologies [8]. While this issue seems to only marginally interest discontinuously occupied historical buildings, it is particularly significant for historical buildings that are used for residential, working and educational purposes, which actually represent the greatest part of the historic buildings stock [8]. Most of historic buildings are currently institutional buildings [9], like schools, universities, town halls and administrative services.

To properly design and operate such buildings, a number of parameters which characterize most of historic institutional buildings, such as large thermal inertia and intermittent and variable usage, should be taken into account [10-13, 28]. Different studies can be found in the literature on procedures to assess and model the energy performance of historic buildings [7, 14-16]. In most cases a need for dynamic simulation of the building energy performance is identified, which allows to properly take into account both the large thermal inertia of such buildings and the effects of intermittent usage and activation of HVAC systems.

In order to enhance thermal comfort and energy savings without undermining cultural, architectural and historical significance, only few solutions can be applied.

One of the main problems for this type of building is the presence of a heating system that is ineffective because it often lacks of an optimized HVAC control system.

The aim of this study is to understand the main characteristics and the heating energy needs of this particular type of buildings and to apply non-invasive energy efficiency solutions. In particular, the proposed solution concerns the improvement of the efficiency of the heating control system.

The aim of this study is therefore to evaluate the energy performance of historical buildings in which a smart heating system thermal control is installed.

The control system allows to take into account the thermal inertia of the building and its intermittent and variable usage. 
The calculation was made using a dynamic simulation software. The building chosen as case study is a relevant historical institutional building in northern Italy, which is used for military and academic purposes. The analysis of the proposed retrofitting solutions is carried out in terms of economy and energy influence.

\section{DESCRIPTION OF THE CASE STUDY}

In this study, the Ducal Palace of Modena has been selected as reference building. This building, home of the Este family for two centuries, is one of the most important Sixteenth Century princely palaces in the world (see Figure 1). The Palace currently houses the Italian Military Academy, the Military Museum and a library [19].

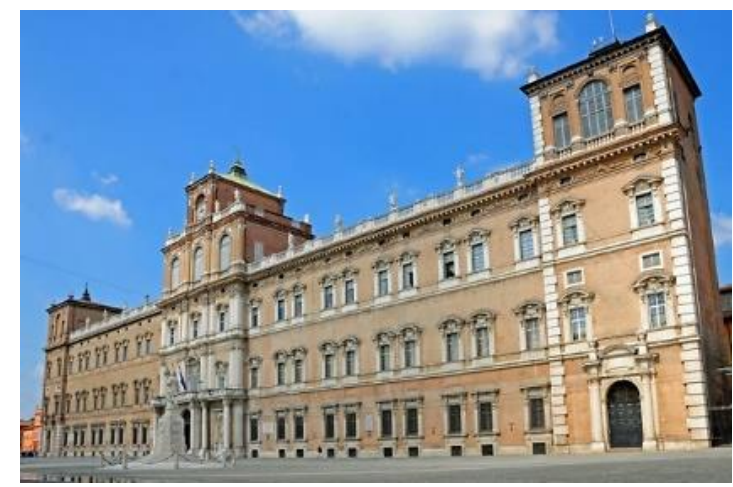

Figure 1. External view of the Ducal Palace of Modena

The building has four floors for a total gross heated volume of about $425,000 \mathrm{~m}^{3}$. The supporting structure is built with rubble masonry and marble is used for the façades decoration. The windows are all wooden-framed and single glazed. The wooden roof supporting structure is mostly covered by tiles. Thickness and thermal transmittance of the envelope components are shown in Table 1.

Table 1. Characteristics of the building envelope components

\begin{tabular}{ccc}
\hline Component type & $\mathrm{s}[\mathrm{m}]$ & $\mathrm{U}\left[\mathrm{W} / \mathrm{m}^{2} \mathrm{~K}\right]$ \\
\hline Wall & 1.04 & 1.2 \\
Window & - & 3.8 \\
Roof & 0.55 & 1.0 \\
Floor & 0.52 & 1.8 \\
\hline
\end{tabular}

In absence of in situ measurements, the thermo-physical properties of the envelope components were assessed by means of on-site inspections and National Technical Standards [20] indicating the material properties of existing Italian buildings. Thermal bridges are not considered since their effect is generally negligible in not-insulated masonry buildings.

The existing heating system is a conventional hydronic one, composed by three gas boilers and radiators often positioned under the windows. The hydronic circuit is largely made by poorly insulated steel tubes for an approximate length of 3000 $\mathrm{m}$, leading to a significantly low distribution efficiency, typical of such large historic buildings. Moreover, the control system is only based on the external temperature, without any room air temperature compensation.

The duration of the heating season is established from October 15th to April 15th, according to the Italian law [21].
A thermal discomfort is generally perceived by occupants, especially during winter time.

Like most historical buildings, in absence of a smart control system, the heating system is currently operated for a certain fixed number of hours per day, as reported in Table 2 .

Table 2. Heating operating hours of the Ducal Palace of Modena

\begin{tabular}{|c|c|c|c|c|}
\hline Period & $\begin{array}{c}\text { M-T-W- } \\
\text { T-F }\end{array}$ & $\begin{array}{c}\text { Hours per } \\
\text { day }\end{array}$ & S-S & $\begin{array}{c}\text { Hours per } \\
\text { day }\end{array}$ \\
\hline $\begin{array}{l}\text { From } 19 / 10 \\
\text { to } 8 / 12\end{array}$ & $\begin{array}{c}6: 00- \\
10: 00 \\
18: 00- \\
22: 00 \\
6 \cdot 00-\end{array}$ & 8 & $\begin{array}{c}6: 00- \\
10: 00 \\
18: 00- \\
22: 00 \\
6: 00-\end{array}$ & ang \\
\hline $\begin{array}{c}\text { From } 9 / 12 \text { to } \\
23 / 12\end{array}$ & $\begin{array}{c}12: 00 \\
18: 00- \\
22: 00\end{array}$ & 10 & $\begin{array}{c}0.00- \\
10: 00 \\
18: 00- \\
22: 00\end{array}$ & 8 \\
\hline $\begin{array}{l}\text { From } 24 / 12 \\
\text { to } 08 / 01\end{array}$ & $\begin{array}{l}7: 00- \\
15: 00 \\
6 \cdot 00-\end{array}$ & 8 & $\begin{array}{l}7: 00- \\
11: 00\end{array}$ & 4 \\
\hline $\begin{array}{c}\text { From } 09 / 01 \\
\text { to } 30 / 03\end{array}$ & $\begin{array}{c}14: 00 \\
18: 00- \\
22: 00\end{array}$ & 12 & $\begin{array}{c}14: 00 \\
18: 00- \\
22: 00\end{array}$ & 12 \\
\hline $\begin{array}{c}\text { From } 31 / 03 \\
\text { to } 15 / 04\end{array}$ & $\begin{array}{c}6: 00- \\
8: 00 \\
17: 00- \\
22: 00\end{array}$ & 7 & $\begin{array}{c}6: 00- \\
8: 00 \\
17: 00- \\
22: 00\end{array}$ & 7 \\
\hline
\end{tabular}

This plant management has two main problems: the building heated volume is very large and it requires to consider many different thermal zones with different uses and heating needs. Furthermore, the current type of heating system operation does not take into account the actual energy needs of the building, which depend on the significant thermal inertia of the walls and internal and solar gains.

\section{DYNAMIC CONTROL OF THE THERMAL SYSTEM AS RETROFITTING SOLUTION}

\subsection{Dynamic control of the thermal system}

The dynamic control of the thermal system as a retrofitting solution is based on a dynamic analysis of the building energy performance.

The proposed control system may allow heating based on the actual needs of each thermal zone. This operation allows energy savings while guaranteeing thermal comfort for the occupants.

\section{METHODOLOGICAL APPROACH}

\subsection{Energy model and calibration}

The simulations have been carried out using TRNSYS 17 dynamic thermal modelling software [24] (see Figure 2).

Given the complexity of the building, the heated volume was divided into 33 zones (see Figure 3, Figure 4 and Figure 5 ) considering only the three main floors. The zones have been defined by combining in rooms with the same intended use and similar solar and internal gains, considering that they may have similar needs in terms of required temperatures and heating operating hours. Zone 10 of the first floor and zone 11 
of the second one (see Figure 4 and Figure 5) have been simulated with a single thermal zone.

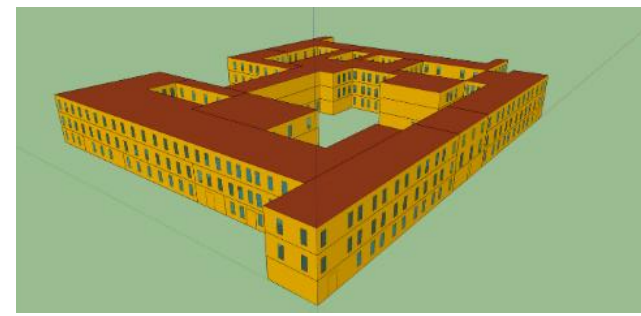

Figure 2. Building simulation model
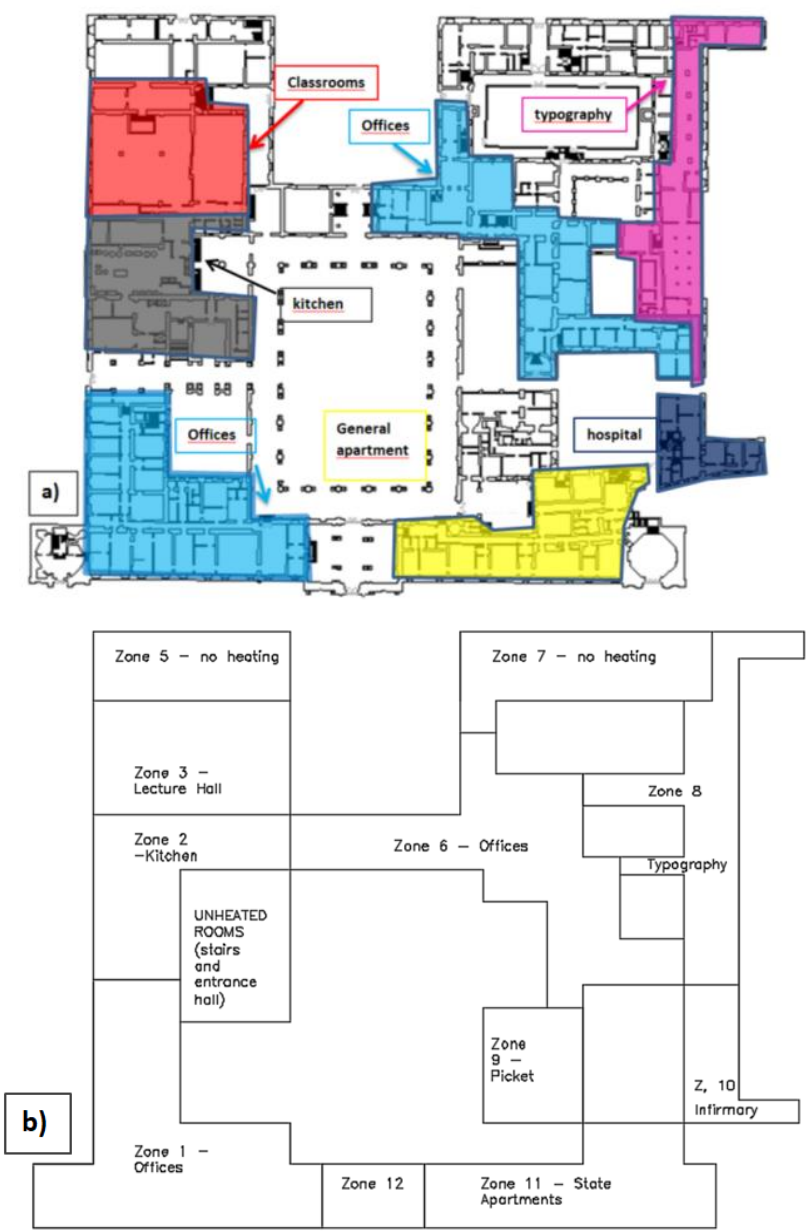

Figure 3. a) Ground floor plan and intended uses. b) Thermal zones of the ground floor in the simulation model

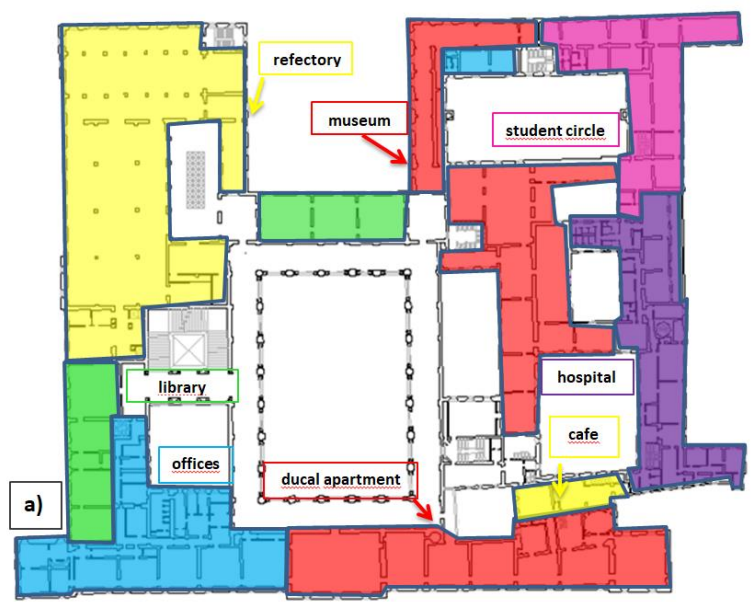

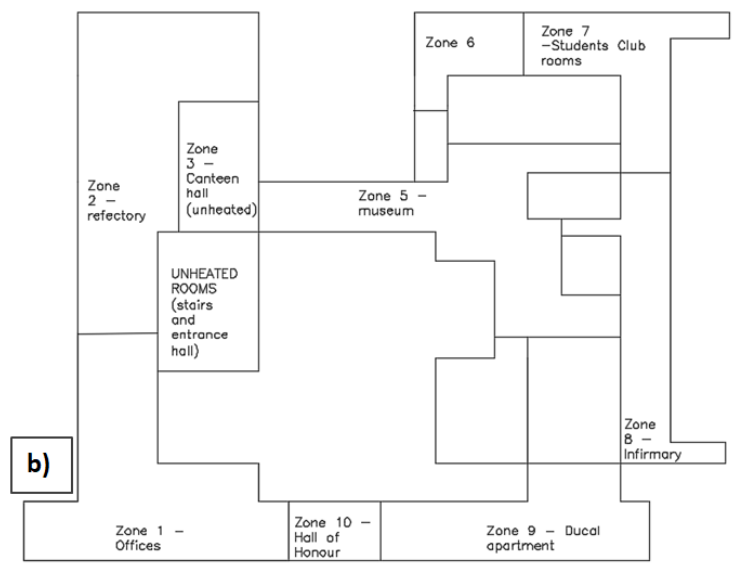

Figure 4. a) First floor and intended uses. b) Thermal zones of the first floor in the simulation model

In the simulation model the air changes per hour are supposed to range from 0.5 to $1 \mathrm{vol} / \mathrm{h}$, according to the rooms different uses, as defined in ISO 13789 [25].

Internal gains, such as lighting, equipment and occupants are defined according to the conventional opening hours of the building. Air infiltration losses have been estimated with the calculation method of ISO 13789 [25]. Such average values are used due to the unavailability of more detailed information.

The simulations were conducted over the heating season. The meteorological data used in the simulations were collected by the University of Modena and Reggio Emilia weather station, which is located in the selected building. The hourly weather data include horizontal global radiation, dry bulb temperature, wind speed and relative humidity [26].

Monthly building energy consumption data from utility billing were used to calibrate the dynamic simulation model of the building. In cases when hourly temperature and relative humidity data are available, a more sophisticated calibration can be carried out.

Once the model of the building envelope was considered calibrated, internal gains were defined for each thermal zone by considering the actual building uses. The heating system efficiency has been estimated with the methods defined in UNI/TS 11300-2 [20], which specifies the national application procedure of different international technical standards, such as EN 15316 [27].

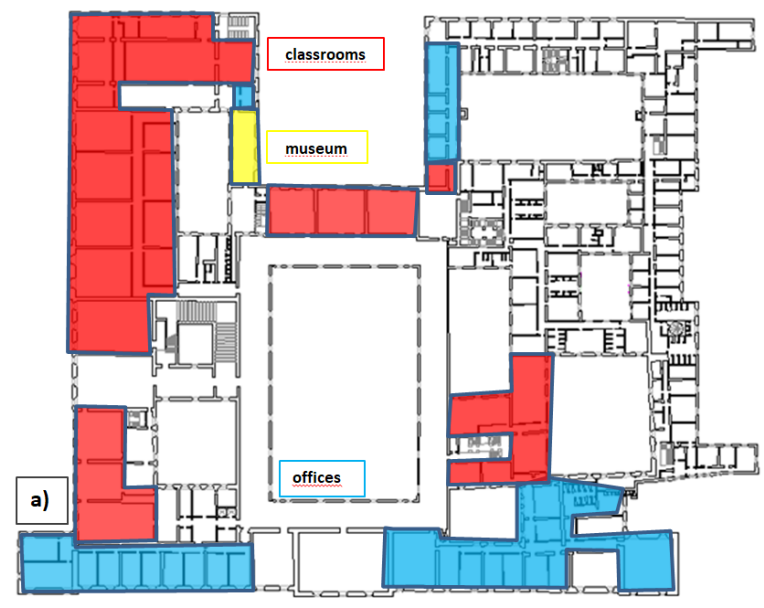




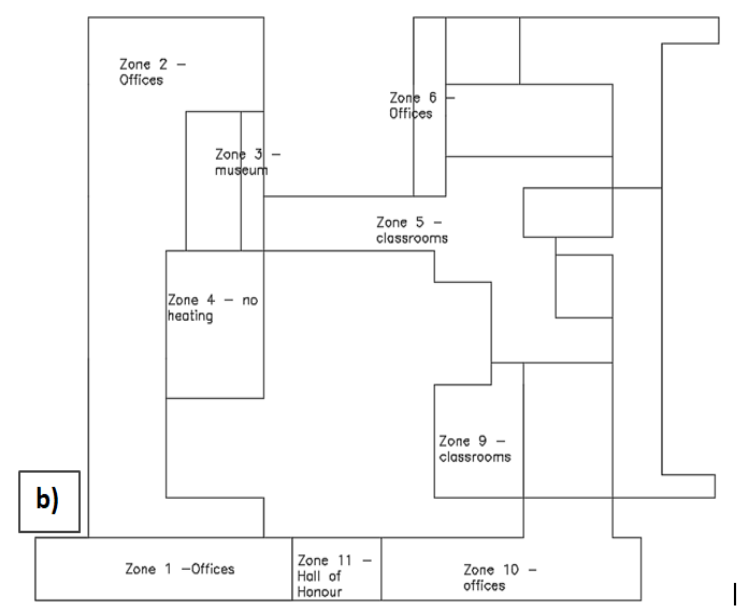

Figure 5. a) Second floor and intended uses. b) Thermal zones of the second floor in the simulation model

\subsection{Retrofitting solution}

Different free floating simulations has been carried out on the case study of the Ducal Palace of Modena, identifying the heating energy saving due to the installation of a high efficiency control system.

By having clearly identifiable thermal zones and with very different thermal requirements, the control will make it possible to significantly increase energy efficiency and comfort within the various rooms and premises. The measure consists in the supply and installation of an advanced temperature control system with a PID control logic installed in a thermal power plant complete with a Building Automation system, digital controller, flow probe, room thermo-probe, climatic probe, 3 -way mixing valve complete with servomotor; pre-adjustable thermostatic valves on the individual radiators complete with motorization with knx wi-fi zone chrono regulators connected to the control unit in the thermal power plant.

\section{RESULTS}

\subsection{Influence of thermal inertia}

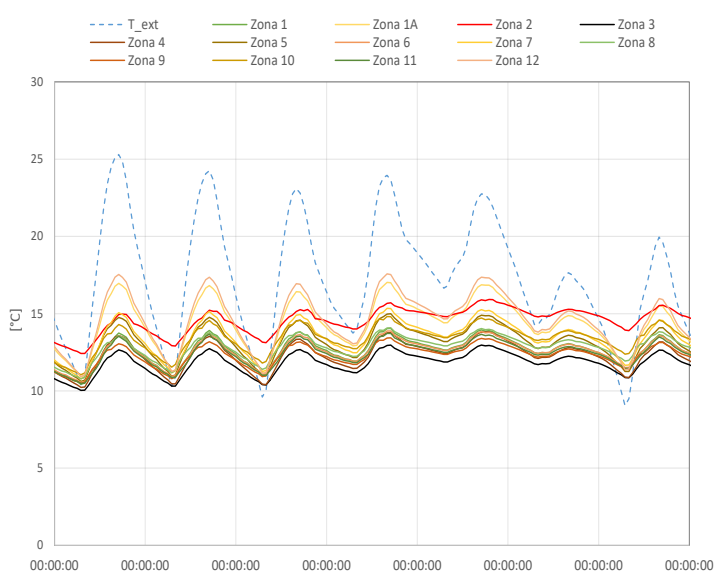

Figure 6. Temperature profile in the ground floor of the building in free-floating condition. Period considered: a representative spring week

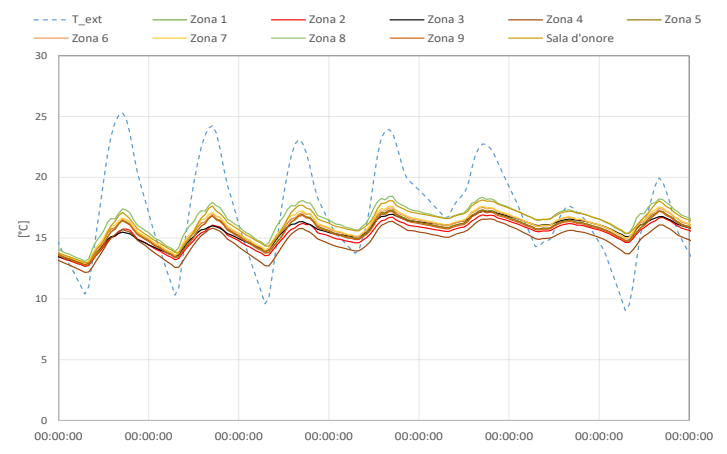

Figure 7. Temperature profile in the first floor of the building in free-floating. Period considered: a representative spring week

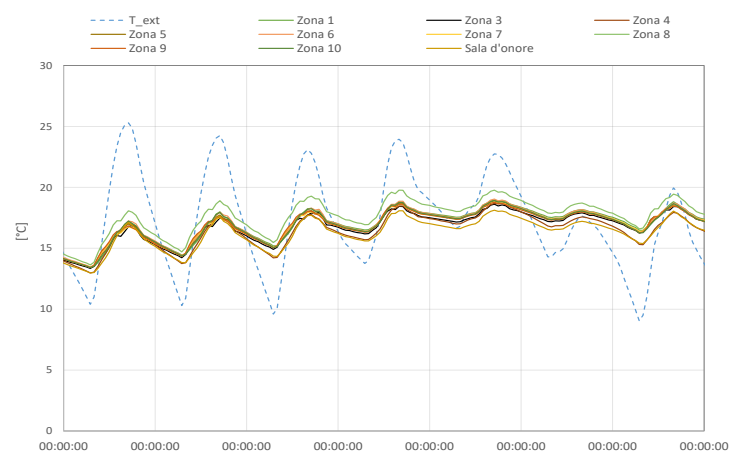

Figure 8. Temperature profile in the second floor of the building in free-floating. Period considered: a representative spring week

Figure 6, Figure 7 and Figure 8 show the diversity of freefloating thermal behavior among thermal zones of the ground floor, first and second floors of the Palace (defined in Figure 3, Figure 4 and Figure 5) during a representative spring week. It is possible to notice how the zones analyzed sometimes have a markedly different thermal behavior, even if they belong to the same floor. The results of the simulations also make it possible to observe the effect of the thermal inertia of the walls, which represents the combined effect of thermal accumulation and thermal resistance of the building envelope component.

\subsection{Energy saving and payback period}

Results are obtained in terms of energy saving and payback period. Figure 9 shows the annual energy need of the existing building and the simulation cases.

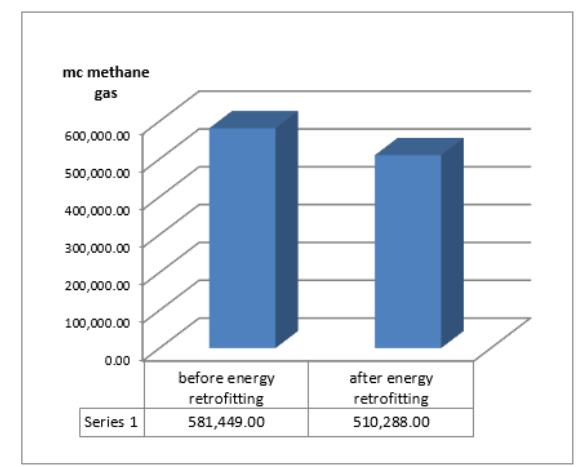

Figure 9. Energy saving for the retrofitting solution 
The results show that the use of a smart control system allows to achieve average reductions in energy needs of about $12 \%$.

Considering an investment cost of about $235.000 €$ for the retrofitting of the control system and a gas price of $0.65 € / \mathrm{mc}$, the payback period is about 5 years.

\section{CONCLUSIONS}

This paper presents a methodology for assessing the potential use of advanced thermal plant control systems for historic buildings. The method is applied to a case study, the Ducal Palace of Modena.

The effects of the retrofitting solutions on energy needs are calculated with a dynamic building simulation model. In absence of detailed measurements, monthly gas consumption from energy billing has been used to calibrate the dynamic model of the building.

The analysis allows to investigate the role of building thermal inertia, as well as internal and solar gains, in optimizing the system functioning.

It also shows the improvement in terms of energy consumption with the installation of the regulation control thermal system.

The results show that energy savings are significant and economically advantageous.

The analysis can be extended to evaluate the impact on the comfort for the occupants and to other climatic contexts to evaluate further advantages and the convenience of the solution in other climatic zones. Future work will also evaluate the additional energy saving potential of the combined effect with other energy efficiency strategies, particularly suitable for historic buildings. The methodology will also be applied to some historic buildings of the University of Modena and Reggio Emilia within the University's Energy Plan.

\section{REFERENCES}

[1] EU Directive 2010/31 of the European Parliament and of the Council of 19 May 2010 on the energy performance of buildings (recast). Off. J. Eur. Union. L153/13, 18.06.2010.

[2] Europe's Buildings under the Microscope. (2012). A country-by-country review of the energy performance of buildings, Brussels, Buildings Performance Institute Europe, BPIE.

[3] ISTAT, Rapporto Bes. Il benessere equo e sostenibile in Italia. 2014.

[4] Berardinis PD, Rotilio M, Marchionni C, Friedman A. (2014). Improving the energy-efficiency of historic masonry buildings. A case study: A minor centre in the Abruzzo region, Italy. Energy Build 80: 415-423. https://doi.org/10.1016/j.enbuild.2014.05.047

[5] Ma Z, Cooper P, Daly D, Ledo L. (2012). Existing building retrofits: Methodology and state-of-the-art. Energy Build 55: 889-902.

[6] http://whc.unesco.org/en/wallmap/, accessed on Jan. 26 , 2016.

[7] Lodi C, Magli S, Contini FM, Muscio A, Tartarini P. (2017). Improvement of thermal comfort and energy efficiency in historical and monumental buildings by means of localized heating based on non-invasive electric radiant panels. Appl. Therm. Eng 126: 276-289. https://doi.org/10.1016/j.applthermaleng.2017.07.071

[8] Milone D, Peri G, Pitruzzella S, Rizzo G. (2015). Are the Best Available Technologies the only viable for energy interventions in historical buildings? Energy Build 95: 39-46. https://doi.org/10.1016/j.enbuild.2014.11.004

[9] Ascione F, Cheche N, Masi RFD, Minichiello F, Vanoli GP. (2015). Design the refurbishment of historic buildings with the cost-optimal methodology: The case study of a $\{X V\}$ century Italian building. Energy Build 99:

162-176. https://doi.org/10.1016/j.enbuild.2015.04.027

[10] Chung MH, Rhee EK. (2014). Potential opportunities for energy conservation in existing buildings on university campus: A field survey in Korea. Energy Build 78: 176182. https://doi.org/10.1016/j.enbuild.2014.04.018

[11] Magli S, Lodi C, Contini FM, Muscio A, Tartarini P. (2016). Dynamic analysis of the heat released by tertiary buildings and the effects of urban heat island mitigation strategies. Energy Build 114: 164-172. https://doi.org/10.1016/j.enbuild.2015.05.037

[12] Yang J, Santamouris M, Lee SE. (2016). Review of occupancy sensing systems and occupancy modeling methodologies for the application in institutional buildings. Energy Build 121: 344-349. https://doi.org/10.1016/j.enbuild.2015.12.019

[13] Yang J, Santamouris M, Lee SE, Deb C. (2016). Energy performance model development and occupancy number identification of institutional buildings. Energy Build 123:

192-204. https://doi.org/10.1016/j.enbuild.2015.12.019

[14] Troi A, Zeno B. (2014). Energy Efficiency Solutions for Historic Buildings. A handbook. Berlin: Birkhäuser.

[15] Santoli LD. (2015). Reprint of 'Guidelines on energy efficiency of cultural heritage. Energy Build 95: 2-8. https://doi.org/10.1016/j.enbuild.2015.02.025

[16] Pisello AL, Petrozzi A, Castaldo VL, Cotana F. (2014). Energy refurbishment of historical buildings with public function: Pilot case study. Energy Procedia 61(0): 660663. https://doi.org/10.1016/j.egypro.2014.11.937

[17] Qu J, Song JR, Qin J, Song ZN, Zhang WD, Shi YX, Zhang T, Zhang HQ, Zhang RP, He ZY, Xue X. (2014). Transparent thermal insulation coatings for energy efficient glass windows and curtain walls. Energy Build 77: 1-10. https://doi.org/10.1016/j.enbuild.2014.03.032

[18] Jelle BP, Kalnæs SE, Gao T. (2015). Low-emissivity materials for building applications: A state-of-the-art review and future research perspectives. Energy Build 96: 329-356. https://doi.org/10.1016/j.enbuild.2015.03.024

[19] Storia dell'Accademia Militare.

[20] Ente Nazionale Italiano di Unificazione - UNI/TS 113002 - Prestazioni energetiche degli edifici - Parte 2: Determinazione del fabbisogno di energia primaria e dei rendimenti per la climatizzazione invernale, per la produzione di acqua calda sanitaria, per la ventilazione e per l'illuminazione in edifici non residenziali. 2014.

[21] DECRETO DEL PRESIDENTE DELLA REPUBBLICA 26 agosto 1993, n. 412 Regolamento recante norme per la progettazione, l'installazione, l'esercizio e la manutenzione degli impianti termici degli edifici ai fini del contenimento dei consumi di energia, in attuazione dell'art. 4, comma 4, della legge 9 gennaio 1991, n. 10.

[22] Mohelnikova J. (2009). Materials for reflective coatings 
of window glass applications. Compat. Plasters Renders Salt Loaded Substrates 23(5): 1993-1998. https://doi.org/10.1016/j.conbuildmat.2008.08.033

[23] http://www.tir100.com/html/downloads.html.

[24] Klein SA. (2004). TRNSYS 16 A TRansient SYstem Simulation Program, User Manual Solar Energy Laboratory, University of Wisconsin-Madison.

[25] EN ISO 13789:2008 - Thermal Performance of Buildings - Transmission and Ventilation Heat Transfer Coefficients - Calculation Method.

[26] Lombroso L. (2012). Annuario delle osservazioni meteoclimatiche dell anno 2012 registrate dall
Osservatorio Geofisico di Modena. Atti SocNatMat Modena.

[27] UNI EN 15316-4-8: 2011 - Heating systems in buildings - Method for calculation of system energy requirements and system efficiencies.

[28] Lodi C, Malaguti V, Contini FM, Sala L, Muscio A, Tartarini P. (2017). University energy planning for reducing energy consumption and GHG emissions: The case study of a university campus in Italy. International Journal of Heat and Technology 35(1): S27-S32. 